Check for updates

Cite this: RSC Adv., 2018, 8, 10686

Received 9th January 2018

Accepted 11th March 2018

DOI: $10.1039 / c 8 r a 00237 a$

rsc.li/rsc-advances

\section{Facile preparation of a tetraethylenepentamine- functionalized nano magnetic composite material and its adsorption mechanism to anions: competition or cooperation $\dagger$}

\begin{abstract}
Meiqin Hu, Haoyu Shen, D * Si Ye, Yan Wang, Jiali Zhang and Shanshan Lv
A tetraethylenepentamine (TEPA)-functionalized nano- $\mathrm{Fe}_{3} \mathrm{O}_{4}$ magnetic composite material ( $\mathrm{nFe} \mathrm{O}_{3} \mathrm{O}$ (TEPA) was synthesized by a facile one-pot solvothermal method. It was characterized by elementary analysis (EA), powder X-ray diffraction (XRD), Fourier transform infrared spectrometry (FTIR), transmission electron microscopy (TEM) and vibrating sample magnetometry (VSM). The results show that the $\mathrm{nFe}_{3} \mathrm{O}_{4}$ (ATEPA has

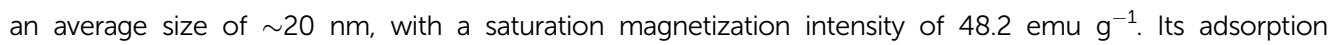
properties were investigated by adsorbing fluorine ions, phosphate, $\mathrm{Cr}(\mathrm{VI})$ and their co-existing water system. The adsorption performance was studied as a function of solution $\mathrm{pH}$, initial concentration of ions, contact time and temperature for each ion. The adsorption of the multi-ion co-existing system was studied via batch tests, XPS and FTIR analyses. The effect of co-existing ions was studied through Box-Behnken Design (BBD) and response surface methodology (RSM). It can be deducted that the adsorption mechanism of an individual fluorine ion or phosphate was mainly related to electrostatic attraction, while that of $\mathrm{Cr}(\mathrm{vI})$ might be mainly related to electrostatic attraction and coordination interactions. For the fluorine ion and phosphate bi-component system, their adsorption was competitive via ion exchange. For the $\mathrm{Cr}(\mathrm{vI})$, fluorine ion and phosphate tri-component co-existing system, $\mathrm{Cr}(\mathrm{vi})$ took priority for adsorption and could replace the absorbed fluorine ion or phosphate by competitive reaction, but not vice versa.
\end{abstract}

\section{Introduction}

Elevated levels of oxyanions (e.g. arsenite, arsenate, chromate, phosphate, selenite, selenate, borate, nitrate, etc.) and monoatomic anions (e.g. fluoride, chloride, bromide, and iodide) have been found in the environment and they can be harmful to both humans and wildlife. ${ }^{1-3}$ Some of these anions have become the most frequently detected in ground water at hazardous waste sites and have been placed on the top of the priority list of toxic pollutants by the U. S. EPA. ${ }^{4}$ Treatment of anion-containing wastewater prior to discharge is essential. Conventional techniques, such as reduction, reverse osmosis, electrodialysis, ion exchange, and adsorption, have been used for removing these anions from wastewater. ${ }^{5,6}$ However, the reduction followed by precipitation has some disadvantages, i.e., higher waste treatment equipment costs, significantly higher consumption of reagents, and significantly higher volume of sludge generated. ${ }^{7}$ Although reverse osmosis and electrodialysis are superior in recovering some of the oxyanions, such as $\mathrm{Cr}(\mathrm{vI})$, it is difficult to

Ningbo Institute of Technology, Zhejiang University, Ningbo, Zhejiang, 31510o, China. E-mail: hyshen@nit.zju.edu.cn

$\dagger$ Electronic supplementary information (ESI) available. See DOI: $10.1039 / \mathrm{c} 8 \mathrm{ra00237a}$ reduce the oxyanions in the effluent to an acceptable level. ${ }^{6}$ As far as ion exchange is concerned, it is an attractive approach in treating the wastewater containing anions, but ion exchange system is the complexity in regenerating the resin. ${ }^{8}$

Recently, $\mathrm{Fe}_{3} \mathrm{O}_{4}$-based magnetic nanoparticles (MNPs) have found to be simple, convenient, and powerful approaches for the separation and purification of environmental samples, and removal of toxic pollutants, including various ions, in water. ${ }^{9-15}$ However, most reports are focused on the treatment of one-ion component solution. Those for co-existing solutions, especially for adsorption mechanism investigating are quite limited..$^{5,9,11}$ The industrial effluents often contain several kinds of oxyanions and monoatomic anions, the study of which is very complicated because of their synergistic, antagonistic or noninteractive effects on their adsorption. The traditional onefactor-at-a-time approach to run and analyze the experiments cannot successfully predict possible interactions between the oxyanions and monoatomic anions in industrial wastewater. Thus, it is necessary to investigate the simultaneous removal process in multi-component system containing oxyanions and monoatomic anions.

Multivariate analysis allows significant reduction in the number of experiments in addition to the description of independent variables impact on the process. This can contribute to 
the development and optimization of the multi-component system while it significantly decreases the cost of experiments. Response surface methodology (RSM) is of the most popular methods applied in researches on adsorption processes. ${ }^{\mathbf{1 6 , 1 7}}$ The RSM is a useful statistical tool used to design experiments in which factors and their levels are determined. After handling the response of the experiments, the results are obtained by analyzing the response according to the RSM. A mathematical model is set via RSM by considering both linear and nonlinear relationships between independent variables, namely factors and response. If interactions affect the response, it can be mathematically modeled which allows for the optimization of the response. Based on such model, response surface graph and contours are provided, which help to visualize the shape of response surface. ${ }^{18,19}$ Thus, simultaneous modeling and optimization of variables are required to achieve an economic and popular wastewater treatment.

In this work, a tetraethylenepentamine (TEPA)-functionalized nano- $\mathrm{Fe}_{3} \mathrm{O}_{4}$ magnetic composite materials ( $\mathrm{nFe}_{3} \mathrm{O}_{4}$ @TEPA) was synthesized by a facile one-pot solvothermal method. It was characterized by elementary analysis (EA), powder X-ray diffraction (XRD), Fourier transform infrared spectrometer (FTIR), transmission electron microscopy (TEM), dynamic light scattering (DLS) and vibrating sample magnetometer (VSM).

The objective of this study is to investigate its adsorption properties of fluorine ion, phosphate, $\mathrm{Cr}(\mathrm{vI})$ and their coexisting water system. On the basis of the adsorption performance investigating of single-component for each ion, the adsorption of multi-component of the co-existing system was statistically studied. Presumed mechanisms were deeply investigated based on batch tests, thermodynamic and kinetic studies, XPS and FTIR characterization and RSM analyses. The overall procedure of the present work was shown in Scheme 1.

\section{Experimental}

\subsection{Materials}

Ferric chloride $\left(\mathrm{FeCl}_{3} \cdot 6 \mathrm{H}_{2} \mathrm{O}\right)$, sodium acetate (NaAc), ethylene glycol (EG), potassium fluoride (KF), potassium dihydrogen phosphate $\left(\mathrm{KH}_{2} \mathrm{PO}_{4}\right)$, potassium dichromate $\left(\mathrm{K}_{2} \mathrm{Cr}_{2} \mathrm{O}_{7}\right)$ were analytical grade, and purchased from Sinopharm Chemical Reagent Co., Ltd. Tetraethylenepentamine (TEPA) was supplied by Aladdin Chemical Reagent Co., Ltd. (Shanghai, China). Distilled water was used to prepare all the solutions. $0.5 \mathrm{~mol} \mathrm{~L}^{-1}$ $\mathrm{HNO}_{3}$ and $0.5 \mathrm{~mol} \mathrm{~L}^{-1} \mathrm{NaOH}$ solutions were used for $\mathrm{pH}$ adjustment.

\subsection{Preparation of $\mathrm{nFe}_{3} \mathrm{O}_{4}$ @TEPA}

The overall preparation of $\mathrm{nFe}_{3} \mathrm{O}_{4} @$ @TEPA was produced using a polyol-media one-pot solvothermal method. $4.0 \mathrm{~g}$ of $\mathrm{FeCl}_{3}$ $\cdot 6 \mathrm{H}_{2} \mathrm{O}$, and $12.0 \mathrm{~g}$ of NaAc were dissolved in $120 \mathrm{~mL}$ ethylene glycol. This solution was stirred vigorously at room temperature for $10 \mathrm{~min}$ to form a stable orange solution. $40 \mathrm{~mL}$ of TEPA was then added with constant stirring for $30 \mathrm{~min}$ until completely dissolved. The mixture solution was then transferred to

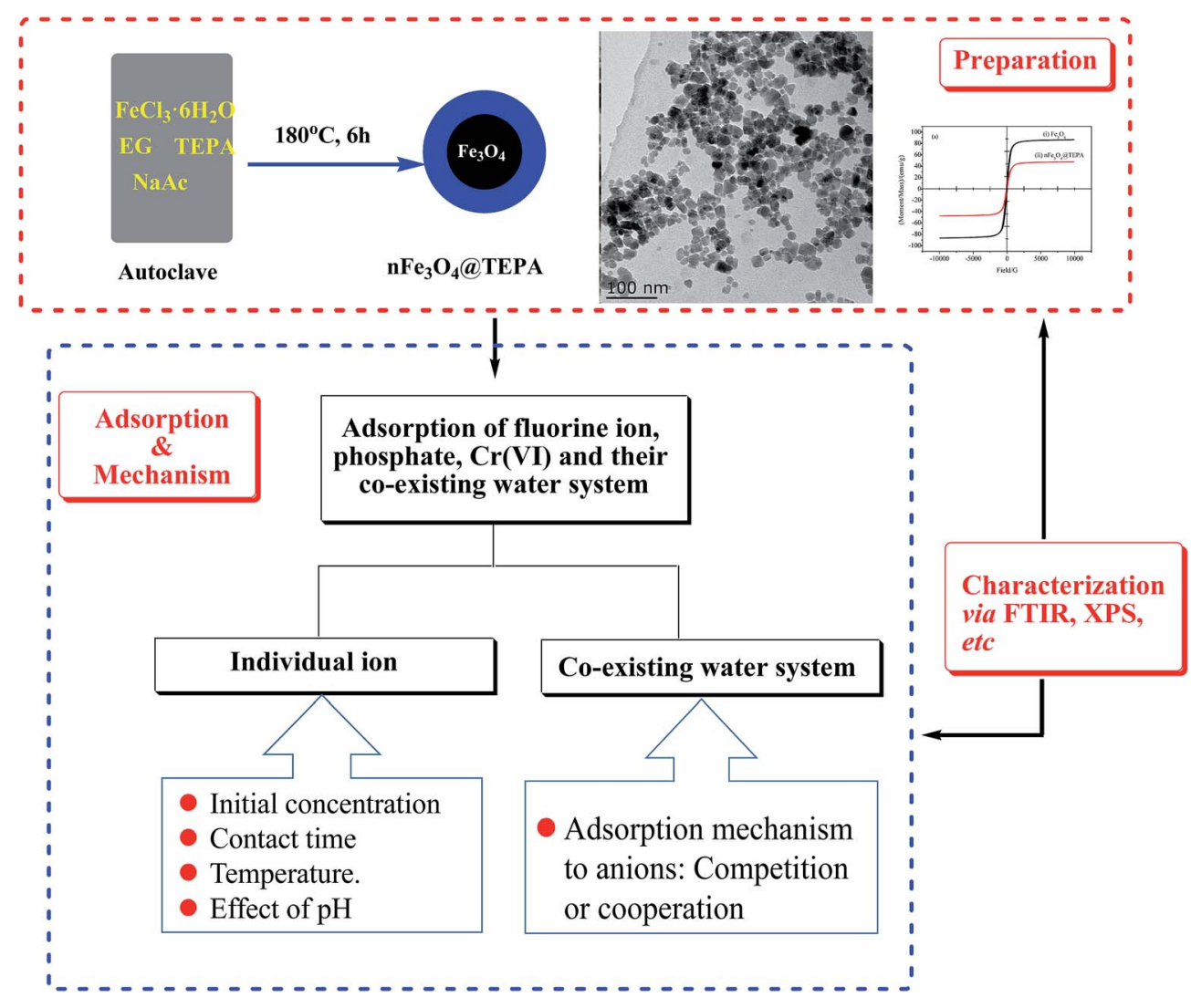

Scheme 1 Overall procedure of the $\mathrm{nFe}_{3} \mathrm{O}_{4}$ (TTEPA facile preparation and its adsorption to anions. 
a Teflon-lined autoclave and heated at $180{ }^{\circ} \mathrm{C}$ for $8 \mathrm{~h}$. After the autoclave cooled to room temperature, the resulting $\mathrm{nFe}_{3} \mathrm{O}_{4} @$ @TEPA was isolated under magnetic field and washed with water and ethanol to remove redundant reagents and impurities. The as-prepared $\mathrm{nFe}_{3} \mathrm{O}_{4} @$ @TEPA was dried in a vacuum oven at $60{ }^{\circ} \mathrm{C}$ for $12 \mathrm{~h}$ and stored in a sealed bottle for further use.

\subsection{Characterization}

Transmission electron microscopy (TEM) images were obtained on a JEM-2100F Lorentz-Transmission Electron Microscopy (TEM) at an accelerating voltage of $200 \mathrm{kV}$. The magnetic properties of magnetic particles were measured using a vibrating sample magnetometer (VSM, Lake Shore 7410). Powder X-ray diffraction (XRD) patterns were collected on an Xray diffractometer (Bruker D8 Advance) with $\mathrm{CuK} \alpha$ radiation at $\lambda$ $=0.154 \mathrm{~nm}$ operating at $40 \mathrm{kV}$ and $40 \mathrm{~mA}$. The elementary analysis results of the nitrogen contents in $\mathrm{nFe}_{3} \mathrm{O}_{4} @$ @TEPA were measured using an elementary analysis (EA, Thermo Fisher Flash-1112). Fourier Transform Infrared spectrometer (FTIR, Thermo Nicolet, USA) and X-ray photoelectron spectroscopy (XPS, AXIS ULTRADLD) were used to investigate the adsorption mechanism. Dynamic light scattering (DLS, Nano ZS-90) was used to determine the mean particle size.

The content of $\mathrm{Fe}_{3} \mathrm{O}_{4}$ in $\mathrm{nFe}_{3} \mathrm{O}_{4} @ \mathrm{TEPA}$ was calculated from the amount of leached $\mathrm{Fe}$, which was measured by using a spectrophotometer (722, Shanghai, China) according to the standard colorimetric method ${ }^{\mathbf{1 1}}$ after digesting $\mathrm{nFe}_{3} \mathrm{O}_{4} @$ @TEPA in $12 \mathrm{~mol} \mathrm{~L}^{-1} \mathrm{HCl}$ solution. The concentration of fluoride ion $\left(\mathrm{F}^{-}\right)$, phosphate or $\mathrm{Cr}(\mathrm{vI})$ in the aqueous solution was analyzed following the standard methods for examination of water and wastewater. $^{20}$ Briefly, the concentration of fluoride ion was carried out using combined fluoride-specific ion-selective electrode carried out using combined fluoride-specific ionselective electrode on a SevenMulti ${ }^{\mathrm{TM}}$ instrument (Mettler Toledo). The concentration of phosphate was analyzed spectrophotometrically by the molybdenum blue method at $690 \mathrm{~nm}$ by adding $\left(\mathrm{NH}_{4}\right)_{6} \mathrm{Mo}_{7} \mathrm{O}_{24}$ and $\mathrm{SnCl}_{2}-\mathrm{HCl}$ solutions followed by being kept in the dark for $10 \mathrm{~min}$ at room temperature (722, Shanghai, China). The concentration of $\mathrm{Cr}(\mathrm{vI})$ ions in the aqueous solution was analyzed with a spectrophotometer at a wavelength of $540 \mathrm{~nm}$ after acidification of samples with $1 \mathrm{~N}$ $\mathrm{H}_{2} \mathrm{SO}_{4}$ and reaction with 1,5-diphenyl carbazide to produce a purple color complex for colorimetric measurement (722, Shanghai, China).

\subsection{Adsorption experiments}

A stock solution of fluoride ion $\left(\mathrm{F}^{-}\right)$, phosphate or $\mathrm{Cr}(\mathrm{vI})$ at concentration of $1000 \mathrm{mg} \mathrm{\textrm {L } ^ { - 1 }}$ was prepared by dissolving a known quantity of potassium fluoride (KF), potassium dihydrogen phosphate $\left(\mathrm{KH}_{2} \mathrm{PO}_{4}\right)$ or potassium dichromate $\left(\mathrm{K}_{2} \mathrm{Cr}_{2} \mathrm{O}_{7}\right)$ in ultrapure water. Batch adsorption experiments were carried out in $150 \mathrm{~mL}$ stoppered flasks, each of which contained $25.00 \mathrm{~mL}$ of fluoride ion $\left(\mathrm{F}^{-}\right)$, phosphate or $\mathrm{Cr}(\mathrm{vI})$ individual solutions or co-existing solutions of varying concentration, from 10 to $1000 \mathrm{mg} \mathrm{L}^{-1}$. A $0.02 \mathrm{~g}$ amount of $\mathrm{nFe}_{3} \mathrm{O}_{4} @$ TEPA was added into each flask and shaken at $150 \mathrm{rpm}$ in a thermostatic shaker. $0.5 \mathrm{~mol} \mathrm{~L}{ }^{-1} \mathrm{HNO}_{3}$ and $0.5 \mathrm{~mol} \mathrm{~L}^{-1}$ $\mathrm{NaOH}$ solutions were used for $\mathrm{pH}$ adjustment, ranging from 2.0 to 10.0. Adsorption kinetic and thermodynamic studies at different temperatures $\left(25-45^{\circ} \mathrm{C}\right)$, with contacting time ranging from 1 to $180 \mathrm{~min}$, were also carried out. Effect of co-existing ions was studied through Box-Behnken Design (BBD) and the response surface methodology (RSM). The post-adsorption solutions were separated magnetically under a NdFeB magnet.

According to the concentrations before and after adsorption, the equilibrium adsorption capacity $\left(q, \mathrm{mg} \mathrm{g}^{-1}\right)$ of the studied anions absorbed to the $\mathrm{nFe}_{3} \mathrm{O}_{4}$ @TEPA is calculated using eqn (1): ${ }^{21}$

$$
q=\frac{\left(C_{0}-C_{\mathrm{e}}\right) V}{m}
$$

where $C_{0}$ and $C_{\mathrm{e}}$ represent the initial solution concentration and the equilibrium concentration of fluoride ion $\left(\mathrm{F}^{-}\right)$, phosphate or $\mathrm{Cr}(\mathrm{vI})\left(\mathrm{mg} \mathrm{L}^{-1}\right), V$ is the volume of the solution $(\mathrm{mL}), m$ is the adsorbent dosage (mg), the same hereinafter.

For the kinetic studies, the pseudo-first-order model (eqn (2)), ${ }^{21}$ pseudo-second-order model (eqn (3)), ${ }^{21,22}$ and intraparticle diffusion model (eqn (4)), ${ }^{21}$ were used to fit the experimental data.

$$
\begin{gathered}
\log \left(q_{\mathrm{e}}-q_{t}\right)=\log q_{\mathrm{e}}-\left(\frac{k_{1}}{2.303}\right) t \\
\frac{t}{q_{t}}=\frac{1}{k_{2} q_{\mathrm{e}}^{2}}+\left(\frac{1}{q_{\mathrm{e}}}\right) t \\
q_{t}=k_{\mathrm{id}} t^{1 / 2}+C
\end{gathered}
$$

where, $q_{\mathrm{e}}$ and $q_{t}$ are the adsorption capacities at equilibrium and at time $t\left(\mathrm{mg} \mathrm{g}^{-1}\right)$, respectively. $k_{1}\left(\min ^{-1}\right), k_{2} \quad(\mathrm{~g}$ $\left.\left(\mathrm{mg}^{-1} \mathrm{~min}^{-1}\right)\right)$ are the adsorption rate constants, $k_{\mathrm{id}}$ is the intraparticle diffusion rate constant $\left(\mathrm{mg}\left(\mathrm{g}^{-1} \mathrm{~min}^{-1 / 2}\right)\right), C$ is the intercept $\left(\mathrm{mg} \mathrm{g}^{-1}\right)$.

For the adsorption isotherm studies, two adsorption isotherms, Langmuir model (eqn (5)) $)^{\mathbf{2 1 , 2 3}}$ and Freundlich model (eqn (6)) were applied to analyze the adsorption data. ${ }^{21,24}$

$$
\begin{gathered}
\frac{C_{\mathrm{e}}}{q_{\mathrm{e}}}=\frac{1}{K_{\mathrm{L}} q_{\mathrm{m}}}+\frac{C_{\mathrm{e}}}{q_{\mathrm{m}}} \\
\log q_{\mathrm{e}}=\log K_{\mathrm{F}}+(1 / n) \log C_{\mathrm{e}}
\end{gathered}
$$

where $q_{\mathrm{m}}$ and $K_{\mathrm{L}}$ are the Langmuir constants related to the maximum adsorption capacity and apparent heat change, respectively, while $K_{\mathrm{F}}$ is a Freundlich constant related to adsorption capacity and $1 / n$ is a Freundlich constant related to the adsorption intensity.

\section{Results and discussion}

\subsection{Characterization of $\mathrm{nFe}_{3} \mathrm{O}_{4} @ \mathrm{TEPA}$}

The TEM images of $\mathrm{nFe}_{3} \mathrm{O}_{4}$ @TEPA were shown in Fig. 1(a). All the size data reflect the averages of about 100 particles and are calculated according to eqn (7): ${ }^{25}$ 


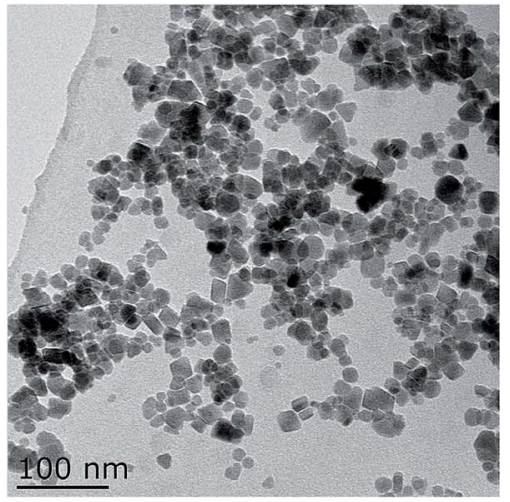

(a)

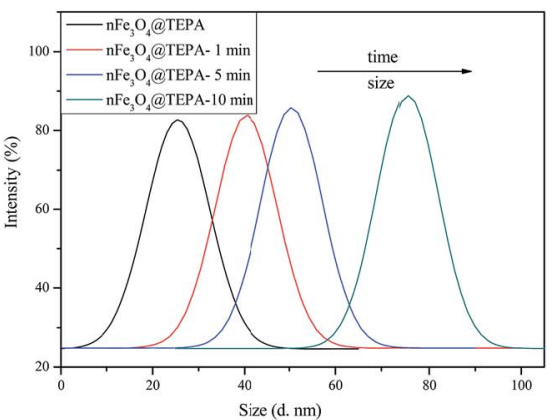

(b)

Fig. 1 TEM image (a) and DLS (b) of $\mathrm{nFe}_{3} \mathrm{O}_{4}$ @TEPA.

$$
\begin{aligned}
U & =D_{\mathrm{w}} / D_{\mathrm{n}}, D_{\mathrm{n}}=\sum_{i=1}^{k} n_{i} D_{i} / \sum_{i=1}^{k} n_{i}, D_{\mathrm{w}} \\
& =\sum_{i=1}^{k} n_{i} D_{i_{i}}{ }^{4} / \sum_{i=1}^{k} n_{i} D_{i}{ }^{3}
\end{aligned}
$$

where $U$ is the polydispersity index, $D_{\mathrm{n}}$ is the number-average diameter, $D_{\mathrm{w}}$ is the weight-average diameter, and $D_{i}$ is the diameter of the determined microspheres. It revealed that the $\mathrm{nFe}_{3}$ $\mathrm{O}_{4} @$ TEPA particles were multidispersed with some aggregation at an average diameter of around $20 \mathrm{~nm}$ (Fig. 1(a)), with $D_{\mathrm{n}}$ at 21.5, $D_{\mathrm{w}}$ at 22.8 , and $U$ at 1.06 . In order to check the aggregation behavior, we carried out the DLS experiments of $\mathrm{nFe}_{3} \mathrm{O}_{4} @$ @TEPA from 0-10 min. As shown in Fig. 1(b), the particles aggregated gradually and the intensity average diameter measured by DLS increased from $25 \mathrm{~nm}$ to $40 \mathrm{~nm}$ after 1 minute, and $75 \mathrm{~nm}$ after 10 minutes. This might be due to the dipolar magnetic interaction between the magnetic cores and hydrogen bonds between the amino groups on the surface of the magnetic cores.

The FTIR spectra of $\mathrm{nFe}_{3} \mathrm{O}_{4}$ and $\mathrm{nFe}_{3} \mathrm{O}_{4}$ @TEPA were showed in Fig. 2(a). Characteristic band of $\mathrm{nFe}_{3} \mathrm{O}_{4}$ occurs at $\sim 589 \mathrm{~cm}^{-1}$. Other typical bands can be assigned as follows, $v(-\mathrm{OH})$ : $\sim 3446 \mathrm{~cm}^{-1}, v\left(-\mathrm{CH}_{2}\right): \sim 2924 \mathrm{~cm}^{-1}, \sim 2853 \mathrm{~cm}^{-1}, \delta\left(-\mathrm{CH}_{2}\right)$ : $\sim 1429 \mathrm{~cm}^{-1}$ for PEG. Compared with $\mathrm{nFe}_{3} \mathrm{O}_{4}$, After functionalization by TEPA, typical bands at $\sim 1573 \mathrm{~cm}^{-1}$ can be assigned to be the stretching and bending vibrations of the $-\mathrm{NH}$ and $-\mathrm{NH}_{2}$ groups appeared, with a great shift of the bands for $\delta\left(-\mathrm{CH}_{2}\right)$. This revealed that the amino groups of TEPA had been successfully grafted to the surface of the $\mathrm{nFe}_{3} \mathrm{O}_{4}$. The superparamagnetic properties of the $\mathrm{nFe}_{3} \mathrm{O}_{4} @$ @EPA were verified by
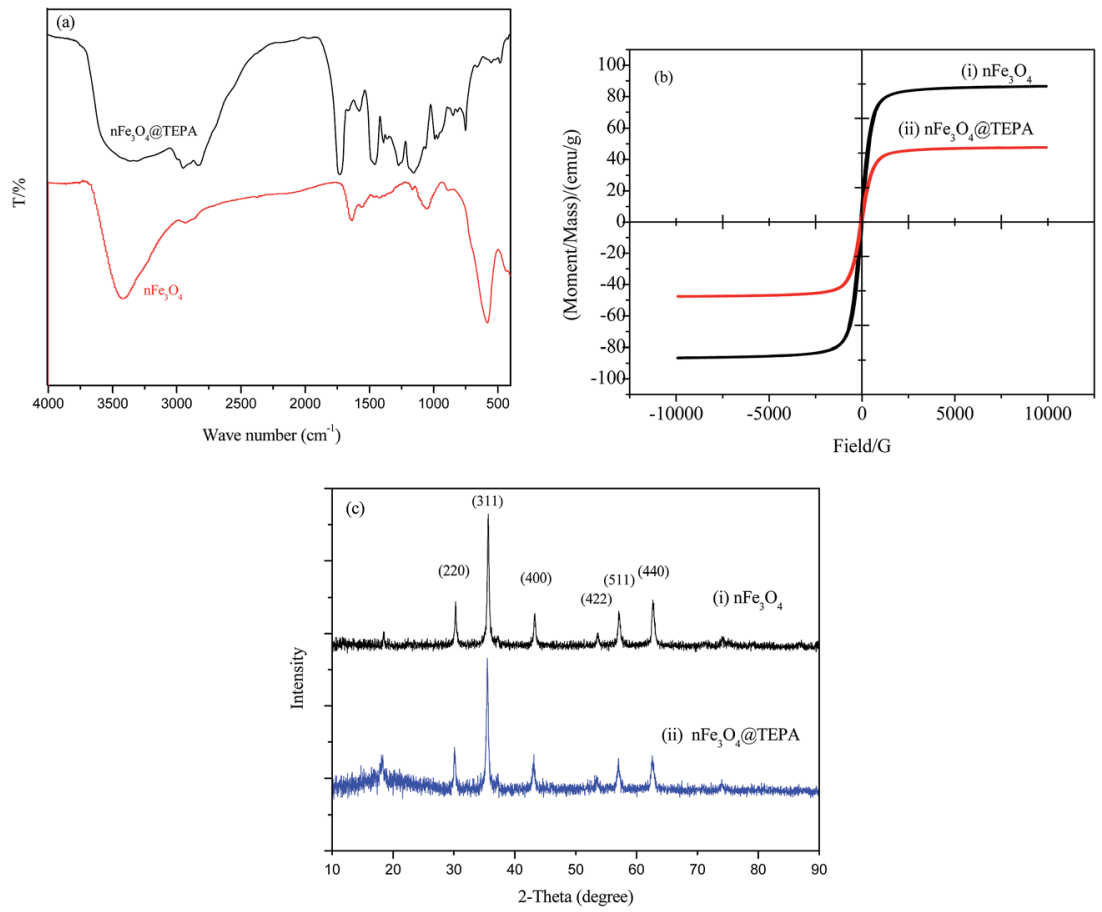

Fig. 2 FTIR (a), VSM (b) and XRD (c) of $\mathrm{nFe}_{3} \mathrm{O}_{4}$ and $\mathrm{nFe}_{3} \mathrm{O}_{4}$ (aTEPA 
the magnetization curve measured by VSM, shown in Fig. 2(b). The saturation moment obtained from the hysteresis loop was found to be $48.2 \mathrm{emu}^{-1}$. The $\mathrm{nFe}_{3} \mathrm{O}_{4} @$ @TEPA was expected to respond well to magnetic fields without any permanent magnetization, therefore making the solid and liquid phases separate easily. Due to the anti-magnetic property of the TEPA, it was no surprise the saturation moment of $\mathrm{nFe}_{3} \mathrm{O}_{4}$ @TEPA lower than that of the naked nano- $\mathrm{Fe}_{3} \mathrm{O}_{4}\left(78.6 \mathrm{emu} \mathrm{g}^{-1}\right.$, as shown in Fig. 2(b)). Interestingly, the saturation moment of the present $\mathrm{nFe}_{3} \mathrm{O}_{4}$ @TEPA was much higher than those of our previously reported nano magnetic polymers (NMPs), which was ranged from 12.3 to $5.56 \mathrm{emu}^{-1}{ }^{-1}{ }^{26}$ which might be due to two facts: (1) anti-magnetic polymer anchored onto the $\mathrm{Fe}_{3} \mathrm{O}_{4}$ core of the NMPs, which leading a decrease of content percentage of $\mathrm{Fe}_{3} \mathrm{O}_{4}$ in the NMPs; (2) by using solvothermal method, amino-groups of TEPA self-assembled graft to the surface of the magnetic cores via hydrogen bonds between the amino groups and active hydroxyl groups of $\mathrm{Fe}_{3} \mathrm{O}_{4}$. The obtained $\mathrm{nFe}_{3} \mathrm{O}_{4}$ @TEPA is with good dispersity to avoid the dispersion agglomeration defects in the traditional preparation process. With a large number of amino groups on the surface of the $\mathrm{nFe}_{3} \mathrm{O}_{4}$, it is beneficial to form magnetic ordered structure, which leading an increase of the saturation moment. This phenomenon was also found by Yoon, et al. ${ }^{27}$ High saturation magnetization (56.1 emu $\mathrm{g}^{-1}$ ) of the $\mathrm{Fe}_{3} \mathrm{O}_{4}$ based magnetic polymer composite material- $\mathrm{Fe}_{3} \mathrm{O}_{4} @ \mathrm{DAPF}$ was found when solvothermal method was used for preparation. To further demonstrate the crystal structure of $\mathrm{nFe}_{3} \mathrm{O}_{4}$ @TEPA, the XRD patterns of the as-prepared $\mathrm{Fe}_{3} \mathrm{O}_{4}$ (without adding TEPA) and $\mathrm{nFe}_{3} \mathrm{O}_{4}$ @TEPA were collected (Fig. 2(c)). It indicated that $\mathrm{nFe}_{3^{-}}$ $\mathrm{O}_{4} @$ @TEPA had retained the spinel structure of $\mathrm{Fe}_{3} \mathrm{O}_{4}$, in which the identical peaks for $\mathrm{Fe}_{3} \mathrm{O}_{4}$ located at $30.1^{\circ}, 35.5^{\circ}, 43.1^{\circ}, 53.4^{\circ}$, $57.0^{\circ}$ and $62.6^{\circ}$, corresponding to their indices (220), (311), (400), (422), (511) and (400) appeared. ${ }^{28}$

Elemental analysis results showed that nitrogen percentage of $\mathrm{nFe}_{3} \mathrm{O}_{4} @$ @EPA was $18.9 \%$, while the total content of $\mathrm{Fe}_{3} \mathrm{O}_{4}$ in the $\mathrm{nFe}_{3} \mathrm{O}_{4} @$ @TEPA was $58.2 \%$, which was higher than those of our previously reported NMPs, and consisted with the VSM results.

\subsection{Adsorption mechanism of the $\mathrm{nFe}_{3} \mathrm{O}_{4} @ T E P A$ to anions}

3.2.1 Effect of $\mathrm{pH}$ and adsorption mechanism for the individual ion. The $\mathrm{pH}$ effect of fluoride ion $\left(\mathrm{F}^{-}\right)$, phosphate or

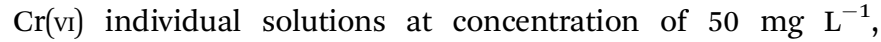
respectively, was investigated with the $\mathrm{pH}$ values ranging from 2.0 to 10.0, and the results were shown in Fig. 3. For $\mathrm{nFe}_{3} \mathrm{O}_{4}$, the adsorption efficiencies of all the three ions were quite low (at around 5\%) and almost not dependent on solution $\mathrm{pH}$, shown in Fig. 3(a). However, the adsorption efficiencies of $\mathrm{nFe}_{3} \mathrm{O}_{4}$ @TEPA were much higher than those of $\mathrm{nFe}_{3} \mathrm{O}_{4}$, at 15.5-99.9\% depending on different ions and $\mathrm{pH}$ values, shown in Fig. 3(b). The high efficiencies might be contributed to the amino-groups of TEPA anchored on the surface of the $\mathrm{nFe}_{3} \mathrm{O}_{4}$. The adsorption efficiency of phosphate or $\mathrm{Cr}(\mathrm{vI})$ was highly dependent on solution $\mathrm{pH}$. Interestingly, unlike phosphate and $\mathrm{Cr}(\mathrm{vI})$, the adsorption capacity of fluoride ion $\left(\mathrm{F}^{-}\right)$was almost not dependent on solution $\mathrm{pH}$. These results imply there might be different adsorption mechanism of $\mathrm{nFe}_{3} \mathrm{O}_{4} @$ @EPA to these three kinds of anions.

The $\mathrm{pH}$ dependency might be related both to the intrinsic structure property of the $\mathrm{nFe}_{3} \mathrm{O}_{4}$ @TEPA and the species of anions. Fig. 4(a) showed that the $\mathrm{pH}_{\mathrm{pzc}}$ of the $\mathrm{nFe}_{3} \mathrm{O}_{4} @$ @TEPA was identified to be 5.02, implying the outer surface of the $\mathrm{nFe}_{3} \mathrm{O}_{4}$ @TEPA is positively charged when $\mathrm{pH}$ is below 5.02, and negatively charged when $\mathrm{pH}$ is above 5.02. Based on the experimental data of the total concentration, we run Visual MINTEQ 3, which is widely used in recent years to simulate equilibria and speciation of inorganic solutes in aqueous solution. ${ }^{29-32}$ The speciation of $\mathrm{Cr}(\mathrm{vI})$, phosphate and fluorine under various $\mathrm{pH}$ was obtained, as shown in Fig. 4(b)-(d).

In the case of $\mathrm{Cr}(\mathrm{vI})$, as shown in Fig. 3, the percentage of uptake $\mathrm{Cr}(\mathrm{vI})$ for $\mathrm{nFe}_{3} \mathrm{O}_{4}$ @TEPA decreased from 99.9\% to 16.8\% gradually with an increase of $\mathrm{pH}$ value from 2.0 to 10.0 . This phenomenon is contributed to the pH-dependent adsorption mechanism. As shown in Fig. 4(b), five main pH-dependent species of $\mathrm{Cr}(\mathrm{vI})$ exist, i.e., $\mathrm{H}_{2} \mathrm{CrO}_{4}, \mathrm{HCrO}_{4}{ }^{-}, \mathrm{CrO}_{4}{ }^{2-}, \mathrm{HCr}_{2} \mathrm{O}_{7}{ }^{-}$, $\mathrm{Cr}_{2} \mathrm{O}_{7}{ }^{2-}$, as described by eqn $8-11$. $\mathrm{Cr}(\mathrm{vI})$ exists mainly in the soluble form of $\mathrm{H}_{2} \mathrm{CrO}_{4}$ at $\mathrm{pH}$ less than 2.0, $\mathrm{HCrO}_{4}{ }^{-}$with $\mathrm{pH}$ from 2.0 to 4.0, and $\mathrm{CrO}_{4}{ }^{2-}$ at $\mathrm{pH}$ value above 6.5.

$$
\begin{gathered}
\mathrm{H}_{2} \mathrm{CrO}_{4} \rightleftharpoons \mathrm{HCrO}_{4}{ }^{-}+\mathrm{H}^{+}: K_{1}=1.58 \times 10^{-1} \\
\mathrm{HCrO}_{4}{ }^{-} \rightleftharpoons \mathrm{CrO}_{4}{ }^{2-}+\mathrm{H}^{+}: K_{2}=3.16 \times 10^{-7} \\
2 \mathrm{HCrO}_{4}^{-} \rightleftharpoons \mathrm{Cr}_{2} \mathrm{O}_{7}{ }^{2-}+\mathrm{H}_{2} \mathrm{O}: K_{3}=3.31 \times 10 \\
\mathrm{HCr}_{2} \mathrm{O}_{7}^{-} \rightleftharpoons \mathrm{Cr}_{2} \mathrm{O}_{7}{ }^{2-}+\mathrm{H}^{+}: K_{4}=1.17
\end{gathered}
$$
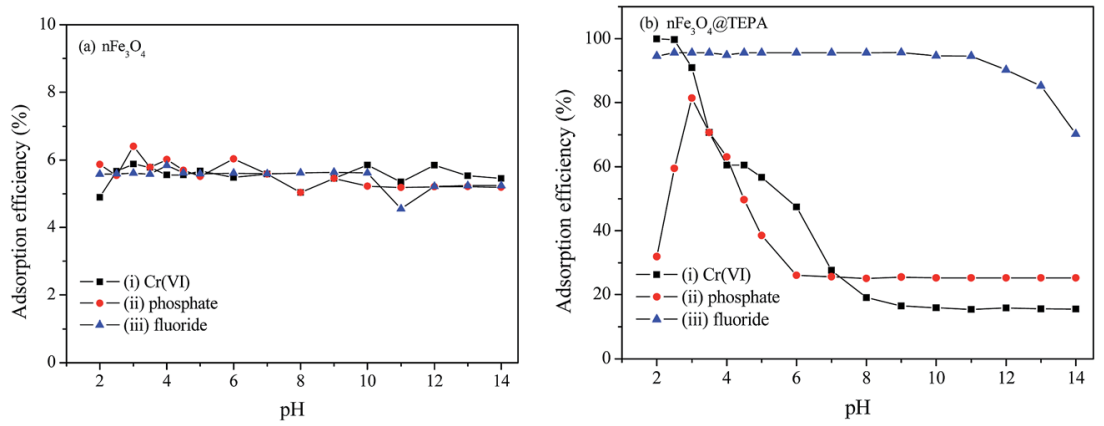

Fig. 3 The $\mathrm{pH}$ effect on the adsorption of fluoride ion $\left(\mathrm{F}^{-}\right)$, phosphate or $\mathrm{Cr}(\mathrm{vl})$ individual solutions at concentration of $50 \mathrm{mg} \mathrm{L}^{-1}$ of $\mathrm{nFe} \mathrm{O}_{4}(\mathrm{a})$ and $\mathrm{nFe}_{3} \mathrm{O}_{4} \mathrm{OTEPA}$ (b). 

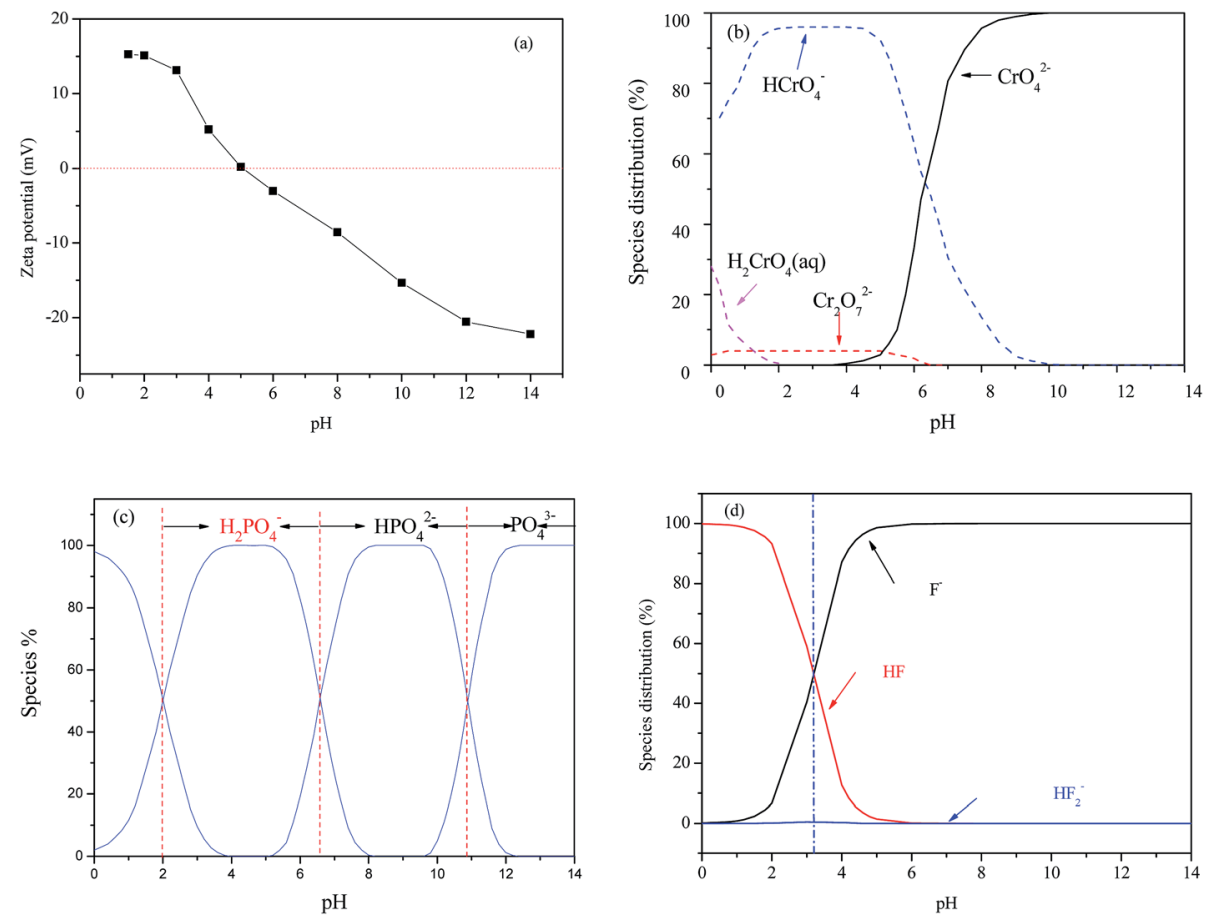

Fig. $4 \mathrm{pH}_{\mathrm{pzc}}$ of the $\mathrm{nFe}_{3} \mathrm{O}_{4}$ (aTEPA (a); distribution diagrams of $\mathrm{Cr}(\mathrm{vI})$ (b), phosphate (c) and fluorine (d) species.

Under acidic conditions ( $\mathrm{pH}$ at 2.0-3.5), amino groups were easier to be protonated $\left(-\mathrm{NH}_{3}{ }^{+}\right)$, as described by eqn (12). Electrostatic attraction happened as in eqn (13), ${ }^{33}$ leading a decrease of the residue concentration of $\mathrm{Cr}(\mathrm{vI})$. With increasing of the $\mathrm{pH}$ value, the concentration of $\mathrm{H}^{+}$was decreased, and at the same time the concentration of $\mathrm{OH}^{-}$, which competed with $\mathrm{HCrO}_{4}{ }^{-}$, was increased. So the ability of $-\mathrm{NH}_{2}$ to be protonated was weakened, resulting in the decline of removal efficiency.<smiles>NNNNNc1ccccc1</smiles>

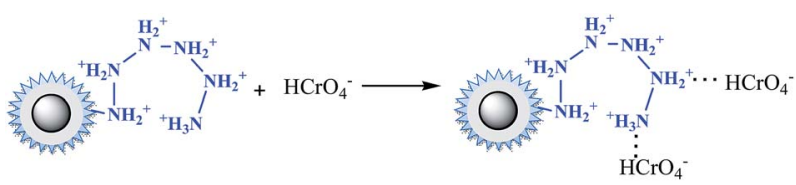

With the increasing of $\mathrm{pH}$ value, an interesting phenomenon was observed that there was a flat, as we found before in aminofunctionalized nano magnetic polymers (NMPs) ${ }^{26}$ This implied that besides the electrostatic attraction and ion exchange interactions, coordination interactions might occur in the adsorption process. as in eqn (14).

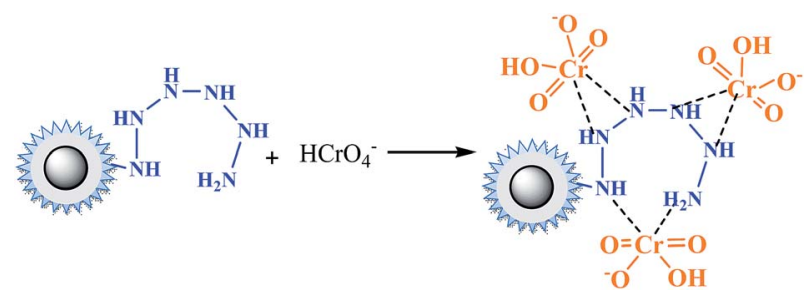

In the case of phosphate, as shown in Fig. 3(c), the percentage of uptake phosphate for $\mathrm{nFe}_{3} \mathrm{O}_{4}$ @TEPA increased from $31.9 \%$ to 81.4\% sharply to a maximum at $\mathrm{pH} 3.0$, then decreased sharply to $26.0 \%$ at $\mathrm{pH}$ 6.0. As shown in Fig. 4(b), phosphate existed in the forms of $\mathrm{H}_{3} \mathrm{PO}_{4}, \mathrm{H}_{2} \mathrm{PO}_{4}{ }^{-}, \mathrm{HPO}_{4}{ }^{2-}$ and $\mathrm{PO}_{4}{ }^{3-}$, depending on the solution $\mathrm{pH}\left(\mathrm{p} K_{1}=2.15, \mathrm{p} K_{2}=7.20\right.$, and $\left.\mathrm{p} K_{3}=12.33\right) \cdot{ }^{34,35}$ With an increase of $\mathrm{pH}$, the $\mathrm{nFe}_{3} \mathrm{O}_{4} @ \mathrm{TEPA}$ surface carried positive charge, and thus would more significantly attract the negatively charged monovalent $\mathrm{H}_{2} \mathrm{PO}_{4}{ }^{-}$ions in solution, which indicated that the physicochemical adsorption due to electrostatic attraction was the predominant process of phosphate removal, as described by eqn (15). When the $\mathrm{pH}$ of the solution increased, the surface became negatively charged, consequently, unfavorable to the phosphate for electrostatic repulsion.

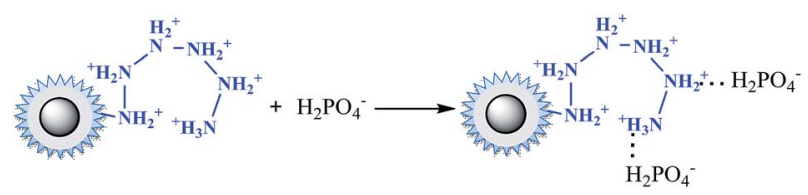


In the case of fluoride, as shown in Fig. 3(d), unlike $\mathrm{Cr}(\mathrm{vI})$ and phosphate, the adsorption capacity was almost not dependent on solution $\mathrm{pH}$. To our knowledge, this is one of the longest $\mathrm{pH}$ ranges of the materials for $\mathrm{F}^{-}$adsorption in literature. The percentage of uptake fluoride for $\mathrm{nFe}_{3} \mathrm{O}_{4}$ @TEPA kept constant at around $95.6 \%$ under $\mathrm{pH}$ value from 2.0 to 11.0 , and gradually decreased to $70.2 \%$ at $\mathrm{pH}$ 14. Such high fluoride removal efficiencies are much better than those in prior reports. For instance, Kong et al. reported the fluoride removal efficiency of $\mathrm{MHS}-\mathrm{MgO} / \mathrm{MgCO}_{3}$ adsorbent was $86.2 \%, 83.2 \%$ and $76.5 \%$ at $\mathrm{pH}=11$ for initial fluoride concentrations of 10, 20 and $30 \mathrm{mg} \mathrm{L}{ }^{-1}$, respectively. ${ }^{36}$ Mohapatra et al. studied the fluoride removal efficiency of $\mathrm{Mg}$-doped nano $\mathrm{Fe}_{2} \mathrm{O}_{3}$ adsorbent was almost $30 \%$ at $\mathrm{pH}=11$ initial fluoride concentration $10 \mathrm{mg} \mathrm{L}{ }^{-1} \cdot{ }^{37}$ Swain et al. demonstrated that the fluoride removal efficiency of $\mathrm{Fe}(\mathrm{III})-\mathrm{Zr}$ (Iv) binary mixed oxide was about $38 \%$ at $\mathrm{pH}=11 .^{38}$ As shown in Fig. 4(c), fluoride mainly existed in the forms of $\mathrm{HF}, \mathrm{F}^{-}$, depending on the solution $\mathrm{pH}(\mathrm{p} K=3.18)$. Although, some literatures ${ }^{38,39}$ showed that in the acidic $\mathrm{pH}$ range $(\mathrm{pH}<5)$, weak hydrofluoric acid (HF) is present in the experiments may affect defluoridation, no obvious decrease of the uptake fluoride was observed in this work. Thus, we assume that besides electrostatic attraction, hydrogen bonds might form in the process of fluoride removal, as described by eqn (16)-(18). In the strongly alkaline range $(\mathrm{pH}>11)$, there is a drop at around $25 \%$ in adsorption percentage, which may be due to the competition of hydroxyl ions with the fluoride and the electrostatic repulsion from the surface of $\mathrm{nFe}_{3} \mathrm{O}_{4} @ \mathrm{TEPA}$.
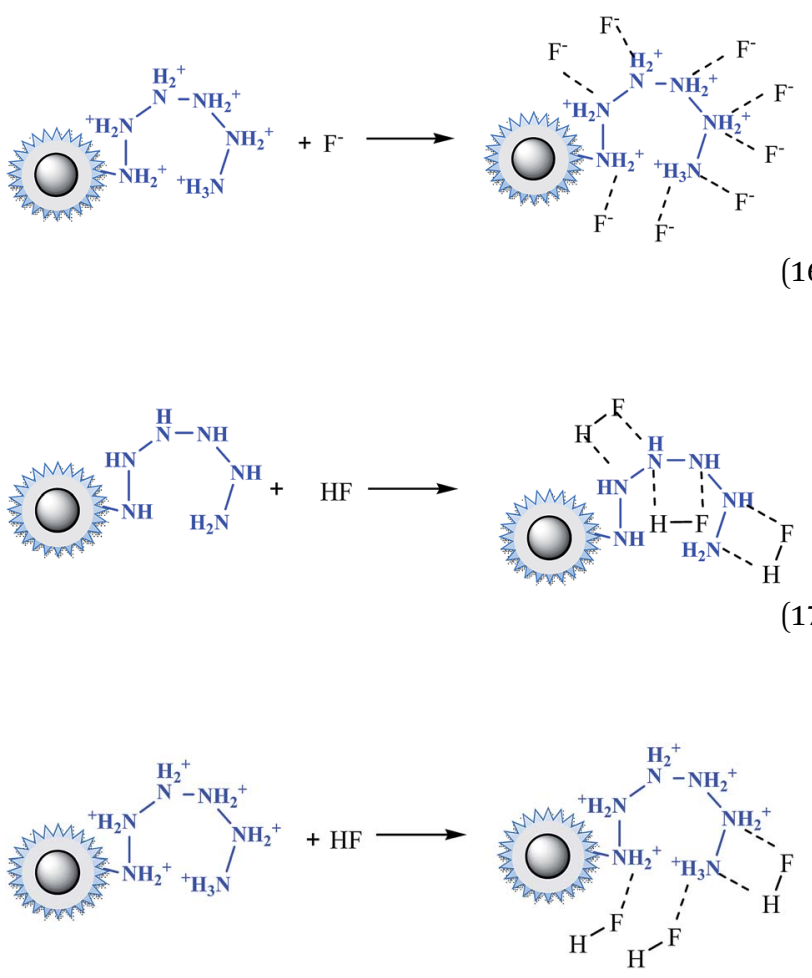

3.2.2 Kinetic studies. Adsorption kinetics of monocomponent fluoride ion $\left(\mathrm{F}^{-}\right)$, phosphate or $\mathrm{Cr}(\mathrm{vI})$ onto
$\mathrm{nFe}_{3} \mathrm{O}_{4} @$ @EPA showed that all the three kinds of anions, the adsorption capacity increased rapidly and reached equilibrium in $10 \mathrm{~min}$ and intra-particle process might not be involved in the rate-limiting steps. The adsorption kinetic experimental data fit the pseudo-second-order model well for all the studied anions. The activation energies of the adsorption process, $E_{\mathrm{a}}$, are found to $19.56 \mathrm{~kJ} \mathrm{~mol}^{-1}, 23.71 \mathrm{~kJ} \mathrm{~mol}^{-1}, 25.35 \mathrm{~kJ} \mathrm{~mol}^{-1}$ for fluoride ion $\left(\mathrm{F}^{-}\right)$, phosphate or $\mathrm{Cr}(\mathrm{vI})$, respectively. All are less than $42 \mathrm{~kJ} \mathrm{~mol}^{-1}$, indicating that diffusion process was the ratecontrolled step. ${ }^{40}$ Detailed discussions were presented in ESI, S1 Kinetic studies and Fig. S1, Table S1 and S2. $\dagger$

3.2.3 Adsorption capacity of $\mathbf{n F e}_{3} \mathrm{O}_{4} @$ @EPA to anions. The adsorption capacities of $\mathrm{nFe}_{3} \mathrm{O}_{4} @$ @TEPA to fluoride ion $\left(\mathrm{F}^{-}\right)$, phosphate or $\mathrm{Cr}(\mathrm{vI})$ mono-component were investigated. Detailed discussions were presented in ESI, S2 Adsorption capacity and Fig. S2, Table S3 and S4. $\uparrow$ The results showed that the Langmuir models fit the data well, suggesting a monolayer adsorption. The maximum adsorption capacities $\left(q_{\mathrm{m}}\right)$ for fluoride ion $\left(\mathrm{F}^{-}\right)$, phosphate or $\mathrm{Cr}(\mathrm{vI})$ are $163.9,149.3$, and $400 \mathrm{mg} \mathrm{L}^{-1}$, respectively. Interestingly, although the adsorption to all the studied anions the $\mathrm{nFe}_{3} \mathrm{O}_{4} @$ @EPA was spontaneous in nature $\left(\Delta G^{\theta}<0\right)$, the enthalpy changes $\left(\Delta H^{\theta}\right)$ for the fluoride ion $\left(\mathrm{F}^{-}\right)$, phosphate or $\mathrm{Cr}(\mathrm{vI})$ were found to be at $38.54,13.89$, $88.03 \mathrm{~kJ} \mathrm{~mol}^{-1}$ (Table $\mathrm{S} 4 \dagger$ ), respectively, which indicated that the adsorption was endothermic. For physical adsorption, the process of adsorption is usually exothermic, that is, the increase of temperature is not favorable to the adsorption. However, chemisorption is some of endothermic, and some of exothermic. In general, it is thought that the increase in temperature is beneficial to chemisorption. ${ }^{41}$ Similar results were found in our previous work ${ }^{\mathbf{1 3 , 1 7}}$ and in literature. ${ }^{\mathbf{4 1}}$

3.2.4 Effect of co-existing ions and presumed mechanism. The effect of co-existing ions experimental studies were investigated with a standard response surface methodology (RSM) design called Box-Behnken Design (BBD). RSM is a useful mathematical and statistical technique for the development of empirical relation between the experimental outputs (responses) and process parameters (factors). A well designed RSM approach leads to optimize the process parameters for improving the responses. The experimental parameters $\left(X_{1}\right.$ (initial concentration of $\mathrm{Cr}(\mathrm{vI}), \mathrm{C}(\mathrm{Cr}(\mathrm{vI}))), X_{2}$ (initial concentration of fluoride ion $\left.\left(\mathrm{F}^{-}\right), \mathrm{C}(\mathrm{F})\right)$, and $X_{3}$ (initial concentration of phosphate, $\mathrm{C}(\mathrm{P})$ ), for design of experiment strategy are considered at three levels and coded as $-1,0$, and +1 for low, middle and high level respectively. The coded and actual values of the independent variables and predicted response of the model were shown in Table S5 and S6. $†$ In the BBD modeling of three factors and three levels, the center point was repeated for five times in order to improve the accuracy in estimation of errors. The response of the model was analyzed by analysis of variance (ANOVA) and a second-order polynomial model (as shown in eqn (19)) was fitted to correlate between the independent variables $\left(X_{1}, X_{2}\right.$ and $\left.X_{3}\right)$ and the response for anions removal in order to predict the of co-existing ions effect.

$$
Y=K_{0}+\sum_{i=1}^{n} K_{i} X_{i}+\sum_{i=1}^{n} K_{i i} X_{i}^{2}+\sum_{1 \leq i \leq j}^{n} K_{i j} X_{i} X_{j}+\varepsilon
$$


where $Y$ represents the predicted response variables i.e. the amount of anions adsorbed by $\mathrm{nFe}_{3} \mathrm{O}_{4} @$ @TEPA, $K_{0}$ is the constant coefficient, $K_{i}$ is the linear coefficient of the input factor $X_{i}, K_{i i}$ is the ith quadratic coefficient of the input factors $X_{i}, K_{i j}$ is the different interaction coefficients between input factors $X_{i}$ and $X_{j}$, and $\varepsilon$ is the error of the model. The software Design Expert (Version 8.0.6.1) was used for model statistic, like experimental design, determination of the coefficients, data analysis and the graph plotting.

The adsorption capacities of $\mathrm{nFe}_{3} \mathrm{O}_{4} @ \mathrm{TEPA}$ to fluoride ion $\left(\mathrm{F}^{-}\right)$, phosphate or $\mathrm{Cr}(\mathrm{vI})$ multi-component solution was carried out by means of BBD of RSM. Quadratic model were used to know the adsorption capacity of the fluoride ion $\left(\mathrm{F}^{-}\right)$, phosphate or $\mathrm{Cr}(\mathrm{VI})$, respectively, shown in ESI eqn (S6)-(S8).† The positive sign and the negative sign of the term indicates the synergetic and antagonistic effect respectively. The ANOVA data shown in Table S7-S9 of ESI $\uparrow$ for Response 1 ( $\mathrm{q}(\mathrm{Cr})$ ), Response 2 $(\mathrm{q}(\mathrm{F})$ ), and Response $2(\mathrm{q}(\mathrm{P}))$, respectively. The coefficient of determination $\left(R^{2}\right)$, which measure the degree of fit in the model was found to be 0.9956, 0.9923, 0.9920 and an Adj- $R^{2}$ of $0.9900,0.9824,0.9817$, respectively. In addition, the model is very significant as evident from its $F$-value and very low probability $p$-value. If the $p$-value is less than 0.05 , it indicates that the model is statistically significant whereas a value higher than 0.05 suggests that the model is not significant. ${ }^{42,43}$ Here, the $F$ values were found to be $177.03,100.01,96.19$, respectively, and $p$-value were all $<0.0001$ for the model.

Values of "Prob $>F$ "less than 0.0500 indicate model terms are significant. As shown in the ANOVA data in Table S7-S9, $\uparrow$ for the adsorption of $\mathrm{Cr}(\mathrm{vI})$, the linear terms, $\mathrm{C}(\mathrm{Cr}(\mathrm{vI}))$ and $\mathrm{C}(\mathrm{P})$ are significant; while for adsorption of fluoride ion $\left(\mathrm{F}^{-}\right)$, besides the linear terms, $\mathrm{C}(\mathrm{F})$, and $\mathrm{C}(\mathrm{P})$, quadratic terms of $\mathrm{C}(\mathrm{F}),{ }^{2}$ and one cross-product coefficients $\mathrm{C}(\mathrm{Cr}(\mathrm{VI})) \mathrm{C}(\mathrm{F})$ and $\mathrm{C}(\mathrm{F}) \mathrm{C}(\mathrm{P})$ are significant; for adsorption of phosphate, except the one cross-product coefficients $\mathrm{C}(\mathrm{F}) \mathrm{C}(\mathrm{P})$ is not significant, all the other model terms are significant.

In response surface plots, the adsorption of anions can be better explained by the interaction of all the three factors. The three dimensional plots and contour plots were used to know the effect of two parameters in their experimental range for the removal of anions while the third parameter remains at zero level. From the shape of contour plot, one could be able to explain the nature and extents of interaction between the experimental factors, i.e., the effects of the co-existing ions in the present work. Circular and elliptical shape of contour plots shows the significant interaction between the experimental factors in the model. Therefore maximum adsorption capacity can be explain on the basics of these experimental factors, i.e., the effects of the co-existing ions, here. The effect of the coexisting fluoride ion $\left(\mathrm{F}^{-}\right)$and phosphate to the adsorption of $\mathrm{Cr}(\mathrm{VI})$ was shown in Fig. 5(a), while the effect of the co-existing $\mathrm{Cr}(\mathrm{vI})$ and phosphate to the adsorption of fluoride ion was shown in Fig. 5(b) and the effect of the co-existing $\operatorname{Cr}(\mathrm{vI})$ and fluoride ion to the adsorption of phosphate was shown in Fig. 5(c), respectively. Those of the bi-component systems were shown in the Fig. S3 in the ESI. $\dagger$ As shown in Fig. 5, for the tricomponent co-existing system, either fluorine ion or phosphate,

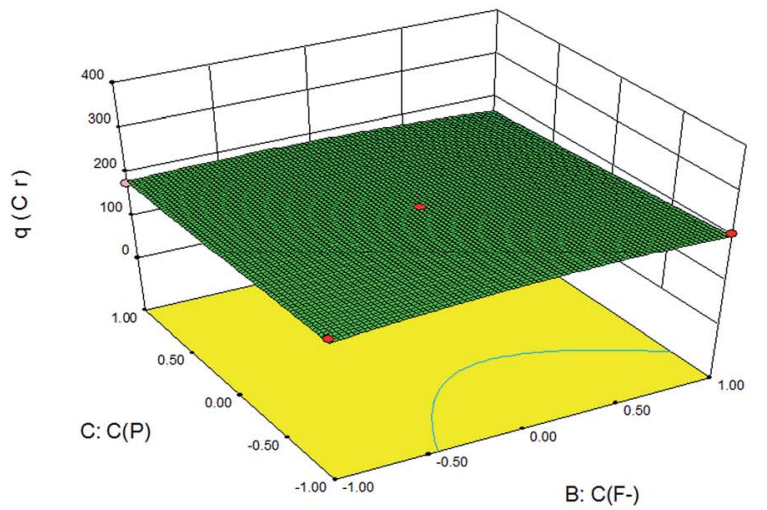

(a)

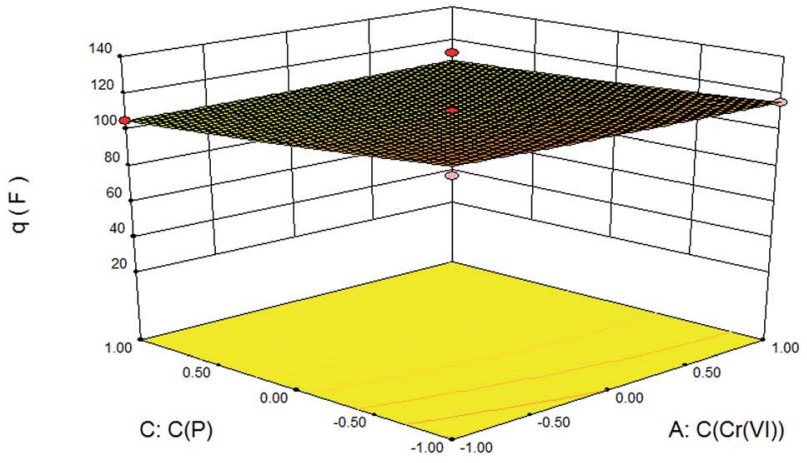

(b)

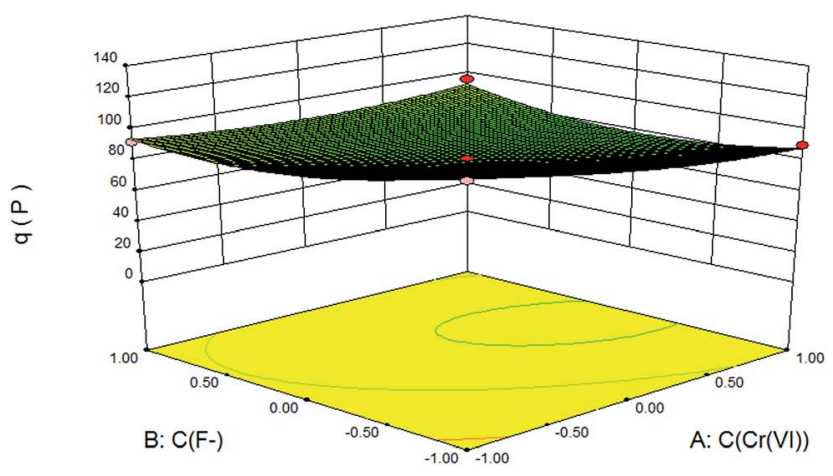

(c)

Fig. 5 The effect of the co-existing fluoride ion and phosphate to the adsorption of $\mathrm{Cr}(\mathrm{vI})$ (a), the co-existing $\mathrm{Cr}(\mathrm{vl})$ and phosphate to the adsorption of fluoride ion (b), the co-existing $\mathrm{Cr}(\mathrm{VI})$ and fluoride ion to the adsorption of phosphate (c).

had little effect on the adsorption competition to $\mathrm{Cr}(\mathrm{vI}) . \mathrm{Cr}(\mathrm{vI})$ took priority for adsorption and could replace the absorbed fluorine ion or phosphate by competitive reaction. As shown in Fig. $\mathrm{S} 3, \uparrow$ for the fluorine ion and phosphate bi-component system, the adsorption of them was competitive via ion exchange.

The adsorption mechanism could be confirmed by XPS and FTIR analyses of $\mathrm{nFe}_{3} \mathrm{O}_{4} @$ @EPA before and after adsorption of the studied anions. The survey scan of XPS spectra of 
$\mathrm{nFe}_{3} \mathrm{O}_{4} @$ TEPA before (a) and after adsorption of phosphate (b) $\mathrm{Cr}(\mathrm{vI})(\mathrm{c})$, fluoride ion (d) and the co-existing the three anions (e) were shown in Fig. 6. From the survey scan of XPS spectra (Fig. 6), new peaks owing to P2p, Cr2p and F1s appeared after adsorption of phosphate (b), after adsorption of $\mathrm{Cr}(\mathrm{vI})$ (c), after adsorption of fluoride ion (d) and after adsorption of the coexisting the three anions (e), suggesting that the phosphate, $\mathrm{Cr}(\mathrm{vI})$ and fluoride ion were successfully adsorbed on the surface of $\mathrm{nFe}_{3} \mathrm{O}_{4} @$ TEPA. High-resolution XPS spectra of $\mathrm{nFe}_{3} \mathrm{O}_{4} @ \mathrm{TEPA}$ after adsorption of the co-existing the three anions were shown in Fig. S4. $\dagger$ As shown in Fig. S4(a), $\dagger$ the characteristic peaks for $\mathrm{Cr}(\mathrm{vI})(\mathrm{Cr} 2 \mathrm{p} \mathrm{1/2,} 587.5 \mathrm{eV}$; Cr2p 3/2, $579.4 \mathrm{eV}$ ) appeared, no obvious peaks assigned to $\mathrm{Cr}(\mathrm{III})$, normally appeared at Cr2p 1/2, 586.3 eV; Cr2p 3/2, $577.1 \mathrm{eV}$, were observed, ${ }^{\mathbf{4 4 , 4 5}}$ which implied that the main species existed in the surface of the $\mathrm{nFe}_{3} \mathrm{O}_{4}$ @TEPA was $\mathrm{Cr}(\mathrm{VI})$, reduction to $\mathrm{Cr}$ (III) hardly occurred, differing from our previous founding. ${ }^{12}$ The characteristic peaks for phosphate (P2p, $113.0 \mathrm{eV})$ and fluoride (F1s, $685.2 \mathrm{eV}$ ) can be found in Fig. S4(b) and (c), $\dagger$ respectively, which clearly confirmed the successful adsorption of phosphate ${ }^{46}$ and fluoride. ${ }^{47}$ As shown in Fig. S4(d), $\dagger$ after adsorption, the peaks of N1s appeared at $398.8 \mathrm{eV}$ with a broader band range, which could be attributed to protonated amine groups $\left(-\mathrm{NH}_{3}{ }^{+}\right)$and the further formation of $-\mathrm{NH}_{3}{ }^{+}$. anions. ${ }^{48}$ Similar phenomena were observed in the XPS spectra of O1s (Fig. 4(e)), peaks of O1s appeared at $\sim 531.1 \mathrm{eV}$ and $\sim 529.5 \mathrm{eV}$, assigned to $\mathrm{C}-\mathrm{O}-\mathrm{C}$ and $\mathrm{C}-\mathrm{OH}$ groups, broadening with a slight shift of binding energies. In the XPS spectra of C1s (Fig. 4(f)), the carbon atoms can be found in two chemically different positions, leading to two differing $\mathrm{C} 1 \mathrm{~s}$ binding energies: $\mathrm{C}-\mathrm{O}-\mathrm{C}$ $(\sim 282.6 \mathrm{eV})$ and $\mathrm{C}-\mathrm{O}-\mathrm{C}(\sim 284.0 \mathrm{eV})$ or $\mathrm{C}-\mathrm{OH}(\sim 286.5 \mathrm{eV})$. Changes in atomic concentration of the key elements after the adsorption were summarized in Table S10. $\dagger$ The main elements of the $\mathrm{nFe}_{3} \mathrm{O}_{4}$ @TEPA were $\mathrm{Fe}, \mathrm{O}, \mathrm{N}$ and $\mathrm{C}$. Compared with the initial pre-adsorbed material, the chromium, phosphate, and

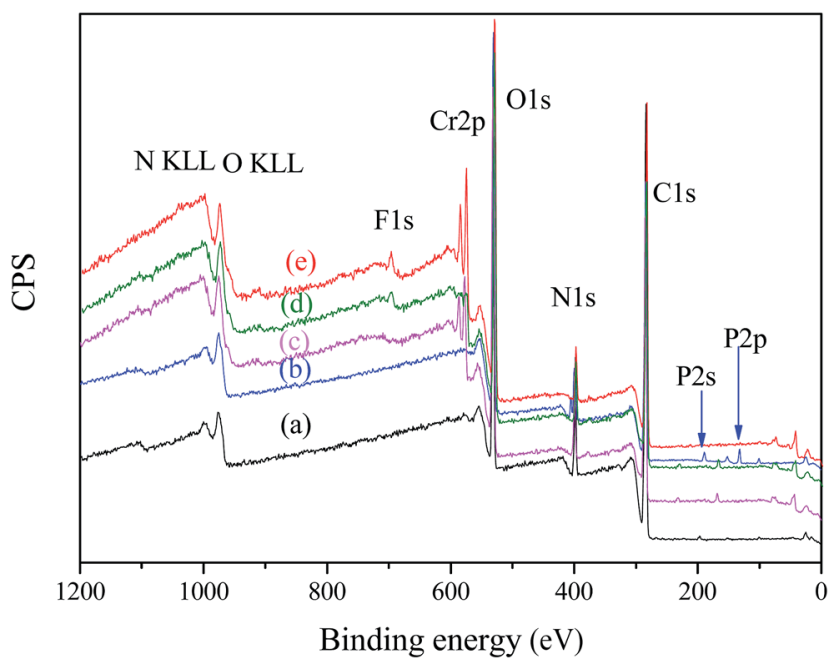

Fig. 6 XPS spectra of $\mathrm{nFe}_{3} \mathrm{O}_{4}$ (aTEPA before adsorption (a), after adsorption of phosphate (b), after adsorption of $\mathrm{Cr}(\mathrm{vI})$ (c), after adsorption of fluoride ion (d) and after adsorption of the co-existing the three anions (e). fluoride atomic percent of the sample was $1.88 \%, 1.01 \%$ and $0.91 \%$ after adsorption experiment. It confirmed that the studied anions were undoubtedly adsorbed onto the surface of $\mathrm{nFe}_{3} \mathrm{O}_{4}$ @TEPA.

The FTIR spectra of $\mathrm{nFe}_{3} \mathrm{O}_{4}$ @TEPA before (a) and after adsorption of phosphate (b), $\operatorname{Cr}(\mathrm{vI})(\mathrm{c})$, fluoride ion (d) and the co-existing the three anions (e) were showed in Fig. 7. In Fig. 7(a), the broad peak appeared at $\sim 3360 \mathrm{~cm}^{-1}$ and $\sim 1573 \mathrm{~cm}^{-1}$ can be assigned to be the stretching and bending vibrations of the $-\mathrm{NH}$ and $-\mathrm{NH}_{2}$ groups. While after adsorption, in Fig. 7(b)-(e) the characteristic bands at $\sim 1573 \mathrm{~cm}^{-1}$ disappeared along with the appearance of the bands at $\sim 1630 \mathrm{~cm}^{-1}$, which may be attributed to the interaction between amino groups and the phosphate, $\operatorname{Cr}(\mathrm{vI})$ and fluoride groups, subsequently weakened the $\mathrm{N}-\mathrm{H}$ bonding and resulted in a large shift $\left(\sim 80 \mathrm{~cm}^{-1}\right)$. The characteristic peaks of $\mathrm{Cr}(\mathrm{vI})$ at $\sim 940 \mathrm{~cm}^{-1}$ and $\sim 760 \mathrm{~cm}^{-1}$ can be observed in the absorption of $\mathrm{HCrO}_{4}{ }^{-}$and the typical peak at $\sim 540 \mathrm{~cm}^{-1}$ for the "Cr-N" also appeared as shown in Fig. 7(b) and (e). The characteristic peaks of the phosphate groups at $543 \mathrm{~cm}^{-1}$ were also observed in Fig. 7(c) and (e), corresponding to the $-\mathrm{P}-\mathrm{O}$ and -O-P-O groups, respectively.

3.2.5 Reusability investigation. The reusable of the $\mathrm{nFe}_{3}$ $\mathrm{O}_{4}$ @TEPA was evaluated by comparing the average adsorption efficiency of a mixture solution of fluoride ion $\left(\mathrm{F}^{-}\right)$, phosphate and $\mathrm{Cr}(\mathrm{vI})$ at each concentration at $20 \mathrm{mg} \mathrm{L}^{-1}$. The postabsorbed $\mathrm{nFe}_{3} \mathrm{O}_{4} @$ @TEPA was extracted with $1 \% \mathrm{NaOH}$ methanol solution for $30 \mathrm{~min}$, and for another adsorption to get the next adsorption efficiency. The results were shown in Fig. 8, indicating that $\mathrm{nFe}_{3} \mathrm{O}_{4}$ @TEPA could be used for at least 10 cycles with a loss of less than $2.8 \%$ upon recovery on average. No obvious decrease in the adsorption capacity efficiency was found. The VSM experiments of the recycled $\mathrm{nFe}_{3} \mathrm{O}_{4} @$ @EPA

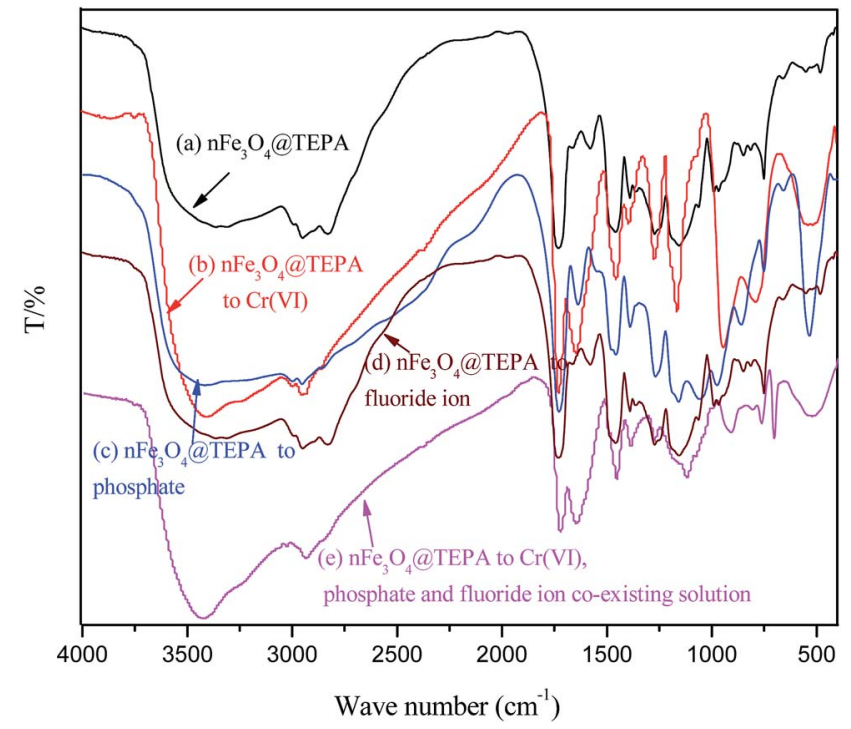

Fig. 7 FTIR spectra of $\mathrm{nFe}_{3} \mathrm{O}_{4}$ (aTEPA before adsorption (a), after adsorption of phosphate (b), after adsorption of $\mathrm{Cr}(\mathrm{VI})$ (c), after adsorption of fluoride ion (d) and after adsorption of the co-existing the three anions (e). 


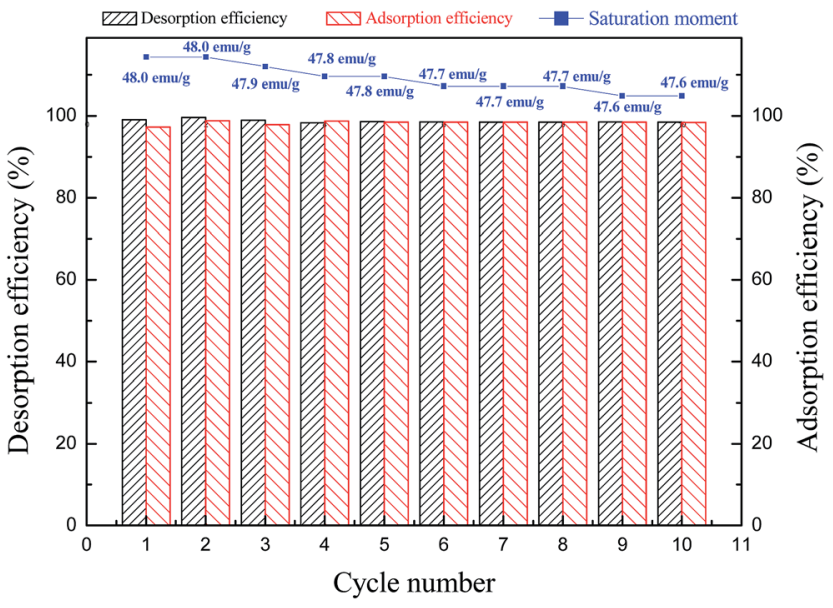

Fig. 8 Reusability of $\mathrm{nFe}_{3} \mathrm{O}_{4}$ (aTEPA after adsorption of a mixture solution of fluoride ion $\left(\mathrm{F}^{-}\right)$, phosphate and $\mathrm{Cr}(\mathrm{VI})$ at each concentration at $20 \mathrm{mg} \mathrm{L}^{-1}$ (insert: saturation moments of the reused $\mathrm{nFe}_{3} \mathrm{O}_{4} \mathrm{a}$ TEPA from 1 cycle to 10 cycles).

were tested. The saturation moments obtained from the hysteresis loops were found to be $48.0-47.6 \mathrm{emu}^{-1}$ from 1 cycle to 10 cycles, (as shown in Fig. 8 (insert)). Compared with the saturation moment of the fresh-prepared $\mathrm{nFe}_{3} \mathrm{O}_{4} @$ @TEPA (48.2 emu $\mathrm{g}^{-1}$ ), which implied that no obvious decrease reduction of the magnetic strength was found.

\section{Conclusion}

A tetraethylenepentamine (TEPA)-functionalized nano- $\mathrm{Fe}_{3} \mathrm{O}_{4}$ magnetic composite materials $\left(\mathrm{nFe}_{3} \mathrm{O}_{4} @\right.$ @EPA) was synthesized by a facile one-pot solvothermal method. The as-prepared $\mathrm{nFe}_{3} \mathrm{O}_{4} @$ $\mathrm{TEPA}$ exhibited a homogeneous morphology, strong affinity ability, and high magnetic responsiveness for the adsorption of ions. The adsorption of the multi-ion co-existing system was studied via batch tests, XPS and FTIR analyses, and analyzed via response surface methodology (RSM). The adsorption mechanism of multi-ion component system was intensively studied.

\section{Conflicts of interest}

There are no conflicts to declare.

\section{Acknowledgements}

We would like to thank the National Natural Science Foundation of China (51608479), the National Natural Science Foundation of Zhejiang Province (LY14B04003), the National College Students' innovation and entrepreneurship training program (201713022009), the Xinmiao Students' innovation training program of Zhejiang Province (2016R401181) for the financial support.

\section{References}

1 J. Zhou, Y. Wang, J. Wang, W. Qia, D. Long and L. Ling, Effective removal of hexavalent chromium from aqueous solutions by adsorption on mesoporous carbon microspheres, J. Colloid Interface Sci., 2016, 462, 200-207.

2 T. R. Zhan, Y. M. Zhang, Q. Yang, H. H. Deng, J. Xu and W. G. Hou, Ultra thin layered double hydroxide nano sheets prepared from a water-in-ionic liquid surfactant-free micro emulsion for phosphate removal from aquatic systems, Chem. Eng. J., 2016, 302, 459-465.

3 B. S. Zhu, Y. Jia, Z. Jin, B. Sun, T. Luo, X. Y. Yu, L. T. Kong, X. J. Huang and J. H. Liu, Controlled synthesis of natro alunite microtubes and spheres with excellent fluoride removal performance, Chem. Eng. J., 2015, 271, 240-251.

4 T. V. Reddy, S. Chauhan and S. Chakraborty, Adsorption isotherm and kinetics analysis of hexavalent chromium and mercury on mustard oil cake, Environ. Eng. Res., 2017, 22, 95-107.

5 G. Darmograi, B. Prelot, A. Geneste, L. C. De Menorval and J. Zaja, Removal of three anionic orange-type dyes and Cr(VI) oxyanion from aqueous solutions onto strongly basic anion-exchange resin. The effect of single-component and competitive adsorption, Colloids Surf., A, 2016, 508, 240-250.

6 L. X. Chen, S. F. Xu and J. H. Li, Recent advances in molecular imprinting technology: current status, challenges and highlighted applications, Chem. Soc. Rev., 2011, 40, 2922-2942.

7 J. Hu, G. H. Chen and I. M. C. Lo, Removal and recovery of $\mathrm{Cr}(\mathrm{VI})$ from wastewater by maghemite nanoparticles, Water Res., 2005, 39, 4528-4536.

8 Y. Q. Xing, X. M. Chen and D. H. Wang, Electrically Regenerated Ion Exchange for Removal and Recovery of Cr(VI) from Wastewater, Environ. Sci. Technol., 2007, 41, 1439-1443.

9 C. M. Su, Environmental implications and applications of engineered nano scale magnetite and its hybrid nano composites: A review of recent literature, J. Hazard. Mater., 2017, 322, 48-84.

10 X. P. Yao, Z. J. Fu, Y. G. Zhao, L. Wang, L. Y. Fang and H. Y. Shen, Use of tetraethylenepentamine-functional $\mathrm{Fe}_{3} \mathrm{O}_{4}$ magnetic polymers for matrix solid phase dispersion extraction and preconcentration of $\mathrm{Cr}(\mathrm{VI})$ in water samples at ultratrace levels, Talanta, 2012, 97, 124-130.

11 H. Y. Shen, S. D. Pan, Y. Zhang, X. L. Huang and H. X. Gong, A new insight on the adsorption Mechanism of aminofunctionalized $\mathrm{Nano}-\mathrm{Fe}_{3} \mathrm{O}_{4}$ magnetic polymers in $\mathrm{Cu}(\mathrm{II})$, Cr(VI) co-existing Water System, Chem. Eng. J., 2012, 183, 180-191.

12 H. Y. Shen, J. L. Chen, H. F. Dai, L. B. Wang, M. Q. Hu and Q. H. Xia, New insights into the sorption and detoxification of chromium (VI) by tetraethylenepentamine functionalized nano-sized magnetic polymer adsorbents: Mechanism and pH effect, Ind. Eng. Chem. Res., 2013, 52, 12723-12732.

13 S. D. Pan, H. Y. Shen, Q. H. Xu, J. Luo and M. Q. Hu, Surface mercapto engineered magnetic $\mathrm{Fe}_{3} \mathrm{O}_{4}$ nanoadsorbent for the removal of mercury from aqueous solutions, J. Colloid Interface Sci., 2012, 365, 204-212.

14 H. Y. Shen, Z. J. Wang, A. M. Zhou, J. L. Chen, M. Q. Hu, X. Y. Dong and Q. H. Xia, Adsorption of phosphate onto 
amine functionalized nano-sized magnetic polymer adsorbents: Mechanism and magnetic effect, RSC Adv., 2015, 5, 22080-22090.

15 S. D. Pan, Y. Zhang, H. Y. Shen and M. Q. Hu, An intensive study on the magnetic effect of mercapto-functionalized nano magnetic $\mathrm{Fe}_{3} \mathrm{O}_{4}$ polymers and their adsorption mechanism for the removal of $\mathrm{Hg}$ (II) from aqueous solution, Chem. Eng. J., 2012, 210, 564-574.

16 A. T. Nair, A. R. Makwana and M. M. Ahammed, The use of response surface methodology for modeling and analysis of water and wastewater treatment processes: a review, Water Sci. Technol., 2014, 69, 464-478.

17 Y. Zhang and B. Pan, Modeling batch and column phosphate removal by hydrated ferric oxide-based nano composite using response surface methodology and artificial neural network, Chem. Eng. J., 2014, 249, 111-120.

18 A. Asfaram, M. Ghaedi and G. R. Ghezelbash, Biosorption of $\mathrm{Zn}^{2+}, \mathrm{Ni}^{2+}$ and $\mathrm{Co}^{2+}$ from water samples onto Yarrowia lipolytica ISF7 using a response surface methodology, and analyzed by inductively coupled plasma optical emission spectrometry (ICP-OES), RSC Adv., 2016, 6, 23599-23610.

19 M. Savasari, M. Emadi, M. A. Bahmanyar and P. Biparva, Optimization of Cd (II) removal from aqueous solution by ascorbic acid-stabilized zero valent iron nano particles using response surface methodology, J. Ind. Eng. Chem., 2015, 21, 1403-1409.

20 APHA and AWWA, Standard Methods for Examination of Water and Wastewater, 20th edn, APHA, AWWA, Washington, DC, New York, 1998.

21 J. Febrianto, A. N. Kosasih, J. Sunarso, Y. H. Ju, N. Indraswati and S. Ismadji, Equilibrium and kinetic studies in adsorption of heavy metals using biosorbent: A summary of recent studies, J. Hazard. Mater., 2009, 162, 616-645.

22 Y. S. Ho, Review of second-order models for adsorption systems, J. Hazard. Mater., 2006, 136, 681-689.

23 S. H. Huang and D. H. Chen, Rapid removal of heavy metal cations and anions from aqueous solutions by an aminofunctionalized magnetic nano-adsorbent, J. Hazard. Mater., 2009, 163, 174-179.

24 K. Y. Foo and B. H. Hameed, Insights into the modeling of adsorption isotherm systems, Chem. Eng. J., 2010, 156, 210.

25 B. Liu, W. Zhang, F. K. Yang, H. L. Feng and X. L. Yang, Facile Method for Synthesis of $\mathrm{Fe}_{3} \mathrm{O}_{4} @$ Polymer Microspheres and Their Application As Magnetic Support for Loading Metal Nano particles, J. Phys. Chem. C, 2011, 115, 15875-15884.

26 Y. G. Zhao, H. Y. Shen, S. D. Pan and M. Q. Hu, Synthesis, characterization and properties of ethylene-diaminefunctionalized $\mathrm{Fe}_{3} \mathrm{O}_{4}$ magnetic polymers for removal of Cr(VI) in wastewater, J. Hazard. Mater., 2010, 182, 295-302.

27 S. Venkateswarlu and M. Y. Yoon, Core-Shell Ferromagnetic Nanorod Based on Amine Polymer Composite ( $\mathrm{Fe}_{3} \mathrm{O}_{4} @ \mathrm{DAPF}$ ) for Fast Removal of $\mathrm{Pb}$ (II) from Aqueous Solutions, ACS Appl. Mater. Interfaces, 2015, 7, 25362-25372.

28 H. Deng, X. L. Li, Q. Peng, X. Wang, J. P. Chen and Y. D. Li, Monodisperse Magnetic Single-Crystal Ferrite Microspheres, Angew. Chem., Int. Ed., 2005, 44, 2782-2785.
29 E. Nehrenheim and J. P. Gustafsson, Kinetic sorption modelling of $\mathrm{Cu}, \mathrm{Ni}, \mathrm{Zn}, \mathrm{Pb}$ and $\mathrm{Cr}$ ions to pine bark and blast furnace slag by using batch experiments, Bioresource Technol., 2008, 99, 1571-1577.

30 E. Vasyukova, O. S. Pokrovsky, J. Viers and B. Dupre, New operational method of testing colloid complexation with metals in natural waters, Appl. Geochem., 2012, 27, 12261237.

31 G. P. Gallios and M. Vaclavikova, Removal of chromium (VI) from water streams: a thermodynamic study, Environ. Chem. Lett., 2008, 6, 235-240.

32 C. Sjostedt, J. P. Gustafsson and S. Kohler, Chemical Equilibrium Modeling of Organic Acids, pH, Aluminum, and Iron in Swedish Surface Waters, Environ. Sci. Technol., 2010, 44, 8587-8593.

33 X. F. Sun, Y. Ma, X. W. Liu, S. G. Wang, B. Y. Gao and X. M. Li, Sorption and detoxification of chromium(VI) by aerobic granules functionalized with polyethylenimine, Water Res., 2010, 44, 2517-2524.

34 Y. Zhang, S. D. Pan, H. Y. Shen and M. Q. Hu, Aminofunctionalized Nano-size Composite Materials for Dispersive Solid Phase Extraction of Phosphate in Water Samples, Anal. Sci., 2012, 28, 887-892.

35 Y. Zhang, X. Q. Xi, S. N. Xu, J. C. Zhou, J. J. Zhou, Q. H. Xu and H. Y. Shen, Adsorption Studies on Phosphate by Amino-functionalized Nano-size Composite Materials, Acta Chim. Sin., 2012, 70, 1839-1846.

36 K. S. Zhang, S. B. Wu, X. L. Wang, J. Y. He, B. Sun, Y. Jia, T. Luo, F. L. Meng, Z. Jin, D. Y. Lin, W. Shen, L. T. Kong and J. H. Liu, Wide $\mathrm{pH}$ range for fluoride removal from water by $\mathrm{MHS}-\mathrm{MgO} / \mathrm{MgCO}_{3}$ adsorbent: Kinetic, thermodynamic and mechanism studies, J. Colloid Interface Sci., 2015, 446, 194-202.

37 M. Mohapatra, T. Padhi, S. Anand and B. K. Mishra, CTAB mediated Mg-doped nano $\mathrm{Fe}_{2} \mathrm{O}_{3}$ : synthesis, characterization, and fluoride adsorption behavior, Desalin. Water Treat., 2012, 50, 376-386.

38 S. K. Swaina, T. Patnaik, P. C. Patnaik, U. Jha and R. K. Dey, Development of new alginate entrapped Fe(III)-Zr(IV) binary mixed oxide for removal of fluoride from water bodies, Chem. Eng. J., 2013, 215, 763-771.

39 A. M. Raichur and M. J. Basu, Adsorption of fluoride onto mixed rare earth oxides, Sep. Purif. Technol., 2001, 24, 121127.

40 E. I. El-Shafey, Removal of $\mathrm{Zn}$ (II) and $\mathrm{Hg}$ (II) from aqueous solution on a carbonaceous sorbent chemically prepared from rice husk, J. Hazard. Mater., 2010, 175, 319-327.

41 N. Azouaou, Z. Sadaoui and A. Djaafri, Adsorption of cadmium from aqueous solution onto untreated coffee grounds: Equilibrium, kinetics and thermodynamics, $J$. Hazard. Mater., 2010, 184, 126-134.

$42 \mathrm{Z}$. Zhang and $\mathrm{H}$. Zheng, Optimization for decolorization of azo dye acid green 20 by ultrasound and $\mathrm{H}_{2} \mathrm{O}_{2}$ using response surface methodology, J. Hazard. Mater., 2009, 172, 1388-1393.

43 M. Amini, H. Younesi, N. Bahramifar, A. Akbar, Z. Lorestani, F. Ghorbani, A. Daneshi and M. Sharifzadeh, Application of 
response surface methodology for optimization of lead biosorption in an aqueous solution by Aspergillus niger, $J$. Hazard. Mater., 2008, 154, 694-702.

44 X. F. Sun, Y. Ma, X. W. Liu, S. G. Wang, B. Y. Gao and X. M. Li, Sorption and detoxification of chromium(VI) by aerobic granules functionalized with polyethylenimine, Water Res., 2010, 44, 2517-2524.

45 S. R. Chowdhury, E. K. Yanful and A. R. Pratt, Chemical states in XPS and Raman analysis during removal of $\mathrm{Cr}(\mathrm{VI})$ from contaminated water by mixed maghemitemagnetite nanoparticles, J. Hazard. Mater., 2012, 235-236, $246-256$.
46 H. B. Ma, J. Li, H. Chen, G. Z. Zuo, Y. Yu, T. H. Ren and Y. D. Zhao, XPS and XANES characteristics of tribofilms and thermal films generated by two P- and/or S-containing additives in water-based lubricant, Tribol. Int., 2009, 42, 940-945.

47 T. Y. Zhu, T. H. Zhu, J. Gao, L. F. Zhang and W. Q. Zhang, Enhanced adsorption of fluoride by cerium immobilized cross-linked chitosan composite, J. Fluorine Chem., 2017, 194, 80-88.

48 Z. Nazarpoor, S. Ma, P. T. Fanson, O. S. Alexeev and M. D. Amiridis, Decomposition of poly(amidoamine)(PAMAM) dendrimers under $\mathrm{O}_{2}$ plasma conditions, Polym. Degrad. Stab., 2012, 97, 439-451. 